Intecoms: Journal of Information Technology and Computer Science

Volume 1 Nomor 1, Juni 2018

e-ISSN : 2614-1574

p-ISSN : 2621-3249

DOI : https://doi.org/10.31539/intecoms.v1i1.164

\title{
SISTEM PAKAR UNTUK MENGIDENTIFIKASI KEPRIBADIAN SISWA MENGGUNAKAN METODE CERTAINTY FACTOR DALAM MENDUKUNG PENDEKATAN GURU
}

\author{
EXPERT SYSTEM TO IDENTIFY STUDENT PERSONALITY USING \\ CERTAINTY FACTOR METHOD IN SUPPORTING TEACHER APPROACH
}

\author{
Nadya Andhika Putri \\ Universitas Pembangunan Panca Budi \\ nadyaandhika@dosen.pancabudi.ac.id
}

\begin{abstract}
Not a few teachers who do not understand the personality of students, in the process of teaching some teachers who do not understand the personality of students then the teacher will be difficult to deliver learning materials that will attract students who impact the knowledge transfer process becomes inhibited. From the problems that have been described previously it is necessary an expert system that can replace an expert in the field of psychology to identify the student's personality. Expert System in this study using Certainty Factor method in representing the knowledge gained. The application design from Expert System itself is designed with web-based, because with web-based applications can help the process of dissemination of information and knowledge with a wider area of distribution.
\end{abstract}

Keywords: Expert System, Certainty Factor, Personality

\begin{abstract}
ABSTRAK
Tidak sedikit guru yang belum memahami kepribadian siswa, dalam proses belajar mengajar beberapa guru ada yang tidak memahami kepribadian siswa maka guru tersebut akan sulit menyampaikan materi pembelajaran yang akan menarik minat siswa yang berdampak kepada proses transfer pengetahuan menjadi terhambat. Dari permasalahan yang telah dipaparkan sebelumnya maka diperlukanlah sebuah sistem pakar yang dapat menggantikan seorang yang ahli dibidang psikologi untuk mengidentifikasi kepribadian siswa. Sistem Pakar dalam penelitian ini menggunakan metode Certainty Factor dalam merepresentasikan pengetahuan yang didapat. Rancangan aplikasi dari Sistem Pakar itu sendiri dirancang dengan berbasis web, karena dengan aplikasi berbasis web dapat membantu proses penyebaran informasi dan pengetahuan dengan daerah penyebaran yang lebih luas.
\end{abstract}

Kata Kunci :Sistem Pakar, Certainty Factor, Kepribadian

\section{PENDAHULUAN}

Perkembangan adalah proses kedewasaan seseorang untuk mengembangkan kemampuan intelektualnya. Perkembangan usia 6-12 tahun adalah masa di mana anak memasuki tahap belajar di sekolah dan di luar sekolah. Anak secara formal belajar di sekolah sehingga menumbuhkembangkan terutama kemampuan kognitifnya. Selain itu anak melakukan berbagai hal di lingkungan rumah yang menumbuhkembangkan kemampuan sosial dan motoriknya. Banyak aspek perilaku pada usia tersebut yang di bentuk melalui penguatan verbal, keteladanan, dan identifikasi. Faktor yang mempengaruhi perkembangan anak tersebut adalah perkembangan fisik dan perkembangan kognitif (Nurihsan, 2013).

Penentuan minat dan bakat perlu dilakukan untuk dapat mengetahui potensi peserta didik, baik dalam segi 
akademis maupun non-akademis. Pengetahuan itu diperlukan saat memberikan pendampingan dan pengembangan keterampilan yang sesuai bakat yang dimiliki. Keterampilan perlu dikembangkan sejak dini untuk dapat mengoptimalkan bakat yang ada pada peserta didik, sehingga dapat bersaing setelah lulus sekolah dalam kehidupan nyata terutama di dunia kerja. Penentuan bakat dan minat dapat memetakan arah pemilihan studi dan pengembangan diri untuk mendapatkan kompetensi dan keterampilan yang dibutuhkan oleh peserta didik

Berdasarkan hasil penentuan bakat dan minat yang dilakukan, guru dapat mengelompokkan peserta didik sehingga lebih mudah untuk menentukan perlakuan dalam mengembangkan bakat dan minat yang dimiliki (Kemendikbud, 2016). Peserta didik dapat pula mengetahui potensi diri dan melihat kelebihan dan kekurangan sehingga dapat mengoptimalkan pengembangan potensinya.

Peserta didik tingkat sekolah dasar berada pada peralihan ke dunia nyata yaitu ketika kemampuan kognitif anak berkembang untuk merencanakan sesuatu (Yulianti, 2016). Usia siswa sekolah dasar yang lebih lanjut (usia 912 tahun) merupakan masa perkembangan keterampilan dan kreativitas serta intelegensi yang sangat pesat. Peran orang tua, guru, dan lingkungan sangat penting bagi perkembangan keterampilan dan kreativitas serta intelegensi anak di usia tersebut. Tanpa bimbingan dan dukungan dari ketiga pihak tersebut maka anak tidak dapat berkembang dengan optimal dan baik (Salisah, 2015).

Sistem pakar merupakan program komputer yang mensimulasikan pemikiran dari para ahli dengan tujuan untuk memecahkan masalah serta membantu dalam proses pengambilan keputusan terhadap masalah tertentu. Sistem pakar merupakan program komputer yang akan mensimulasikan pemikiran dari para ahli dengan tujuan untuk memecahkan masalah dan membantu dalam proses pengambilan keputusan terhadap masalah tertentu. Hal itulah yang membedakan antara Sistem pakar dengan program yang bersifat konvensional ataupun yang bersifat tradisional.

Definisi lain, Sistem Pakar adalah suatu program komputer yang mensimulasikan penilaian dan perilaku manusia atau organisasi yang memiliki pengetahuan dan pengalaman ahli dalam bidang tertentu. Biasanya sistem itu mengandung basis pengetahuan, akumulasi pengalaman dan perangkat aturan untuk menerapkan kodisi setiap suatu situasi tertentu yang dijelaskan dalam suatu program. Sistem pakar yang canggih dapat ditingkatkan dengan penambahan basis pengetahuan atau seperangkat aturan. Dengan kata lain, ini adalah sistem berbasis software yang membuat atau mengevaluasi keputusan berdasarkan aturan yang ditetapkan dalam perangkat lunak (Josephine dan Jeyabalaraja, 2012).

Keuntungan dari sistem pakar dibandingkan program konvensional adalah bahwa algoritma inti mereka tidak dirumuskan dalam kode pemrograman tetapi disimpan sebagai pengetahuan dalam database independen yang disebut pengetahuandasar atau KB (Bassiel, 2012). Penerapan teknologi informasi dalam sistem kesehatan diperlukan dalam rangka memberikan layanan yang cepat, efektif, dan efesien kepada seseorang (Mateo \& Jaewan, 2008).

Keuntungan dari Sistem Pakar dibandingkan program konvensional adalah bahwa algoritma inti mereka 
tidak dirumuskan dalam kode pemrograman tetapi disimpan sebagai pengetahuan dalam database independen yang disebut pengetahuandasar atau knowledge based.

Dari permasalahan yang telah dipaparkan sebelumnya maka diperlukanlah sebuah sistem pakar yang dapat menggantikan seorang yang ahli dibidang psikologi untuk proses mengidentifikasi kepribadian siswa.

Sistem ini diharapkan dapat membantu masyarakat luas yang awam terhadap ilmu pengetahuan psikologi dalam mengetahui kepribadian seseorang.

\section{METODE PENELITIAN}

Sistem Pakar dalam penelitian ini menggunakan metode Certainty Factor dalam merepresentasikan pengetahuan yang didapat. Rancangan aplikasi dari Sistem Pakar itu sendiri dirancang dengan berbasis web, karena dengan aplikasi berbasis web dapat membantu proses penyebaran informasi dan pengetahuan dengan daerah penyebaran yang lebih luas.

Pengumpulan data dilakukan dengan cara wawancara langsung dengan Guru BK dan melakukan studi literatur yang berisi mengenai kepribadian siswa.

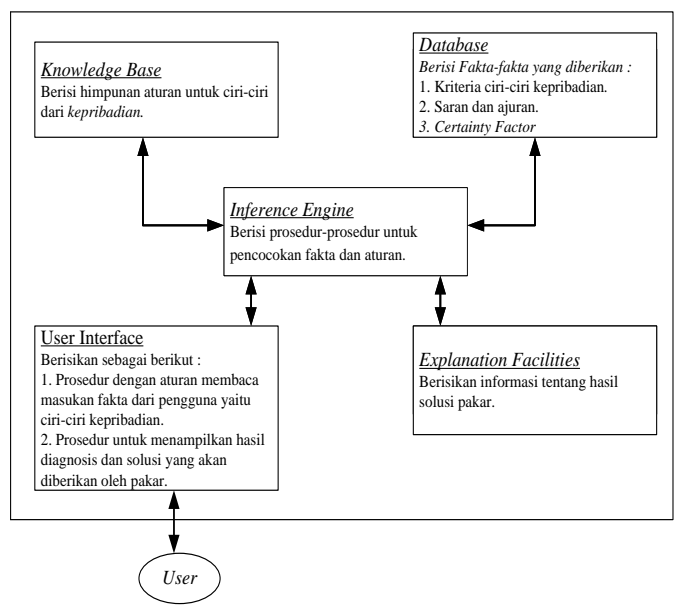

Gambar 1 Desain Arsitektur Sistem Pakar
Jadi rumus untuk Certainty factor adalah sebagai berikut (Giarattano dan Riley, 1994):
$C F(H \mid E)=$
$M B(H \mid E)$
$M D(H \mid E)$
Di mana :

$C F(H / E): \quad$ Certainty factor dari hipotesis $\mathrm{H}$ yang dipengaruhi oleh gejala (evidence) E. Besarnya CF berkisar antara -1 sampai dengan 1. Nilai -1 menunjukkan ketidakpercayaan mutlak sedangkan 1 menunjukkan kepercayaan mutlak.

$\mathrm{MB}(\mathrm{H} \mid \mathrm{E})$ : $\quad$ Ukuran kenaikan kepercayaan (measure of increased belief) terhadap hipotesis $\mathrm{H}$ yang dipengaruhi oleh gejala $\mathrm{E}$.

$\mathrm{MD}(\mathrm{H} \mid \mathrm{E}) \quad$ Ukuran kenaikan

: $\quad$ ketidakpercayaan (measure creased disbelief) terhadap hipotesis $\mathrm{H}$ yang dipengaruhi oleh gejala E.

$H$ : Hipotesis atau dugaan penyakit.

E: $\quad$ Evidence (Peristiwa atau fakta)

Pemberian nilai untuk pembagian tingkat keyakinan dapat dilihat pada Tabel 1 (Intanet. Al, 2010).

Tabel 1 Tingkat Keyakinan CF

\begin{tabular}{|c|c|c|}
\hline $\begin{array}{l}\text { Kondisi } \quad \text { tidak } \\
\text { (Uncertain }\end{array}$ & pasti & $\mathbf{C F}$ \\
\hline Pasti Tidak (Definetely & Not) & 0.2 \\
\hline $\begin{array}{l}\text { Hampir Pasti Tidak } \\
\text { Certainty Not) }\end{array}$ & (Almost & 0.3 \\
\hline $\begin{array}{l}\text { Kemungkinan Besar } \\
\text { (Probably Not) }\end{array}$ & Tidak & 0.4 \\
\hline $\begin{array}{l}\text { Kemungkinan Tidak } \\
\text { Not) }\end{array}$ & (Maybe & 0.5 \\
\hline Tidak Tahu (Unknown) & & 0.6 \\
\hline Kemungkinan (Maybe) & & 0.7 \\
\hline $\begin{array}{l}\text { Kemungkinan } \\
\text { (Probably) }\end{array}$ & Besar & 0.8 \\
\hline $\begin{array}{l}\text { Hampir } \\
\text { Certainty) }\end{array}$ & (Almost & 0.9 \\
\hline Pasti (Definitely) & & 1.0 \\
\hline
\end{tabular}


Nilai 0 menggambarkan bahwa user tidak mengalami gejala tersebut, namun semakin tinggi nilai $\mathrm{Cf}$ yang dipilih maka persentasi untuk gejala tersebut juga berkemungkinan tinggi dialami user. Kemudian masing-masing aturan baru dihitung certainty factornya, sehingga diperoleh nilai certainty factor untuk masing-masing aturan, kemudian nilai certainty factor tersebut dikombinasikan.

Certainty factor menggambarkan derajat kepercayaan atau tidak kepercayaan, dimana hasil dari penjumlahan keduanya tidak selalu berjumlah 1.Certainty factor menggunakan $\mathrm{MB}(\mathrm{H} \mid \mathrm{E})$ untuk menggambarkan nilai kepercayaan dari hipotesis $\mathrm{H}$, Gejala E, dan $\mathrm{MD}(\mathrm{H} \mid \mathrm{E})$ untuk nilai ketidakpercayaan dari hipotesis $\mathrm{H}$, gejala E. Karena keterangan atau fakta bagian dari gejala salah satunya menyangkal hipotesis, $\mathrm{MB}(\mathrm{H} \mid \mathrm{E})$ atau $\mathrm{MD}(\mathrm{H} \mid \mathrm{E})$ maka nilainya harus nol untuk setiap $\mathrm{H}$ dan $\mathrm{E}$.

Certainty Factor untuk kaidah dengan kesimpulan yang serupa (Similiarly Concluded Rules) :

CFCombine $C F[H \mid E] 1,2=C F[H \mid E] 1$ $+C F[H \mid E] 2 *[1-C F[H \mid E] 1] \ldots \ldots . .(2)$ CFCombine $C F[H \mid E]$ old,3 $3=$ CF[H|E]old $+C F[H \mid E] 3 \quad * \quad[1 \quad-$ $C F[H \mid E]$ old $] \ldots \ldots . . .(3)$

Kelebihan dari metode ini adalah cocok digunakan pada sistem pakar yang mengukur sesuatu yang pasti atau tidak pasti seperti mendiagnosis penyakit dan perhitungan dari metode ini hanya berlaku untuk sekali hitung, serta hanya dapat mengolah dua data sehingga keakuratannya terjaga (Halim dan Hansun, 2015).

\section{HASIL DAN PEMBAHASAN}

Sistem Pakar untuk mengidentifikasi kepribadian siswa ini dimulai dengan pengumpulan data yang didapatkan dari seorang pakar, kemudian data tersebut akan dibuat menjadi basis pengetahuan untuk membangun Sistem Pakar mengidentifikasi Psikopat ini.

Berikut data yang telah diperoleh dari wawancara dengan Guru BK mengenai jenis kepribadian beserta ciricirinya. Data jenis Kepribadian dapat dilihat pada tabel 2 sebagai berikut :

Tabel. 2 Jenis Kepribadian

\begin{tabular}{lll}
\hline No & \multicolumn{1}{c}{$\begin{array}{c}\text { Jenis } \\
\text { Kepribadian }\end{array}$} & Kode Jenis \\
\hline 1 & Sanguinis & K001 \\
2 & Koleris & K002 \\
3 & Melankolis & K003 \\
4 & Pleghmatis & K004 \\
\hline
\end{tabular}

Ciri-ciri kepribadian siswa dapat dilihat pada tabel 3 sebagai berikut

Tabel. 3 Tabel Ciri-ciri Kepribadian

\begin{tabular}{|c|c|c|}
\hline NO & Ciri-ciri & $\begin{array}{l}\text { Kode Ciri- } \\
\text { ciri }\end{array}$ \\
\hline 1 & $\begin{array}{l}\text { Anda seseorang yang } \\
\text { mudah berpikir positif }\end{array}$ & $\mathrm{C} 001$ \\
\hline 2 & $\begin{array}{l}\text { Anda seseorang yang } \\
\text { mudah berpikir negatif }\end{array}$ & $\mathrm{C} 002$ \\
\hline 3 & $\begin{array}{l}\text { Anda seseorang yang } \\
\text { banyak bicara daripada } \\
\text { mendengarkan }\end{array}$ & $\mathrm{C} 003$ \\
\hline 4 & $\begin{array}{l}\text { Anda seseorang yang } \\
\text { mudah berteman dan } \\
\text { mudah berbaur }\end{array}$ & $\mathrm{C} 004$ \\
\hline 5 & $\begin{array}{l}\text { Anda seseorang yang } \\
\text { penuh semangat }\end{array}$ & $\mathrm{C} 005$ \\
\hline 6 & $\begin{array}{l}\text { Anda seseorang yang } \\
\text { penuh rasa ingin tahu }\end{array}$ & $\mathrm{C} 006$ \\
\hline 7 & $\begin{array}{ll}\text { Anda seseorang yang } \\
\text { menyenangkan } & \text { dan } \\
\text { selalu terlihat ceria } & \end{array}$ & $\mathrm{C} 007$ \\
\hline 8 & $\begin{array}{l}\text { Anda seseorang yang } \\
\text { menyukai hiburan dan } \\
\text { membuat orang lain } \\
\text { terhibur }\end{array}$ & $\mathrm{C} 008$ \\
\hline 9 & $\begin{array}{l}\text { Anda seorang yang } \\
\text { mampu meyakinkan } \\
\text { orang lain dengan logika } \\
\text { dan fakta }\end{array}$ & $\mathrm{C} 009$ \\
\hline 10 & Anda seseorang yang & $\mathrm{C} 010$ \\
\hline
\end{tabular}




\begin{tabular}{|c|c|c|}
\hline & $\begin{array}{l}\text { berkemauan tegas dan } \\
\text { kuat }\end{array}$ & \\
\hline 11 & $\begin{array}{lr}\text { Anda } & \text { seseorang yang } \\
\text { sangat } & \text { memerlukan } \\
\text { perubahan } & \end{array}$ & $\mathrm{C} 011$ \\
\hline 12 & $\begin{array}{l}\text { Anda seseorang yang } \\
\text { berbakat memimpin }\end{array}$ & C012 \\
\hline 13 & $\begin{array}{l}\text { Anda seseorang yang } \\
\text { melakukan sesuatu yang } \\
\text { berorientasi tujuan }\end{array}$ & C013 \\
\hline 14 & $\begin{array}{l}\text { Anda seseorang yang } \\
\text { mudah percaya diri dan } \\
\text { mandiri }\end{array}$ & C014 \\
\hline 15 & $\begin{array}{l}\text { Anda seseorang yang } \\
\text { mudah tersinggung dan } \\
\text { sensitif }\end{array}$ & C015 \\
\hline 16 & $\begin{array}{l}\text { Anda seseorang yang } \\
\text { penuh pikiran dan suka } \\
\text { menganalisa }\end{array}$ & C016 \\
\hline 17 & $\begin{array}{l}\text { Anda seseorang yang } \\
\text { suka membuat rencana } \\
\text { dan terjadwal }\end{array}$ & C017 \\
\hline 18 & $\begin{array}{lr}\text { Anda seseorang yan } \\
\text { menuntut kesempurnaan } \\
\text { (perfeksionis } \\
\text { idealis) }\end{array}$ & C018 \\
\hline 19 & $\begin{array}{lr}\text { Anda seseorang } & \text { yang } \\
\text { menyukai } & \text { detail } \\
\text { terhadap hal } & \text { kecil } \\
\text { maupun besar } & \end{array}$ & C019 \\
\hline 20 & $\begin{array}{lll}\text { Anda seseorang } & \text { yang } \\
\text { cerewet dan } & \text { suka } \\
\text { mengkritik } & & \end{array}$ & $\mathrm{C} 020$ \\
\hline 21 & $\begin{array}{lr}\text { Anda seseorang } & \text { yang } \\
\text { cinta damai } & \text { serta } \\
\text { menghindari } & \text { segala } \\
\text { bentuk kekacauan } & \end{array}$ & $\mathrm{C} 021$ \\
\hline 22 & $\begin{array}{l}\text { Anda seseorang yang } \\
\text { rendah hati }\end{array}$ & $\mathrm{C} 022$ \\
\hline 23 & $\begin{array}{l}\text { Anda seseorang yang } \\
\text { penurut dan toleran }\end{array}$ & $\mathrm{C} 023$ \\
\hline 24 & $\begin{array}{l}\text { Anda seseorang yang } \\
\text { pemalu dan pendiam }\end{array}$ & $\mathrm{C} 024$ \\
\hline 25 & $\begin{array}{l}\text { Anda seorang yang } \\
\text { penakut }\end{array}$ & $\mathrm{C} 025$ \\
\hline 26 & $\begin{array}{l}\text { Anda seorang yang sabar } \\
\text { dan ramah }\end{array}$ & $\mathrm{C} 026$ \\
\hline
\end{tabular}

Untuk penalaran dalam Sistem Pakar mengidentifikasi kepribadian siswa, maka data yang diperoleh dari pakar akan direpresentasikan dalam bentuk pohon keputusan yang sebagaimana terlihat pada gambar sebagai berikut :

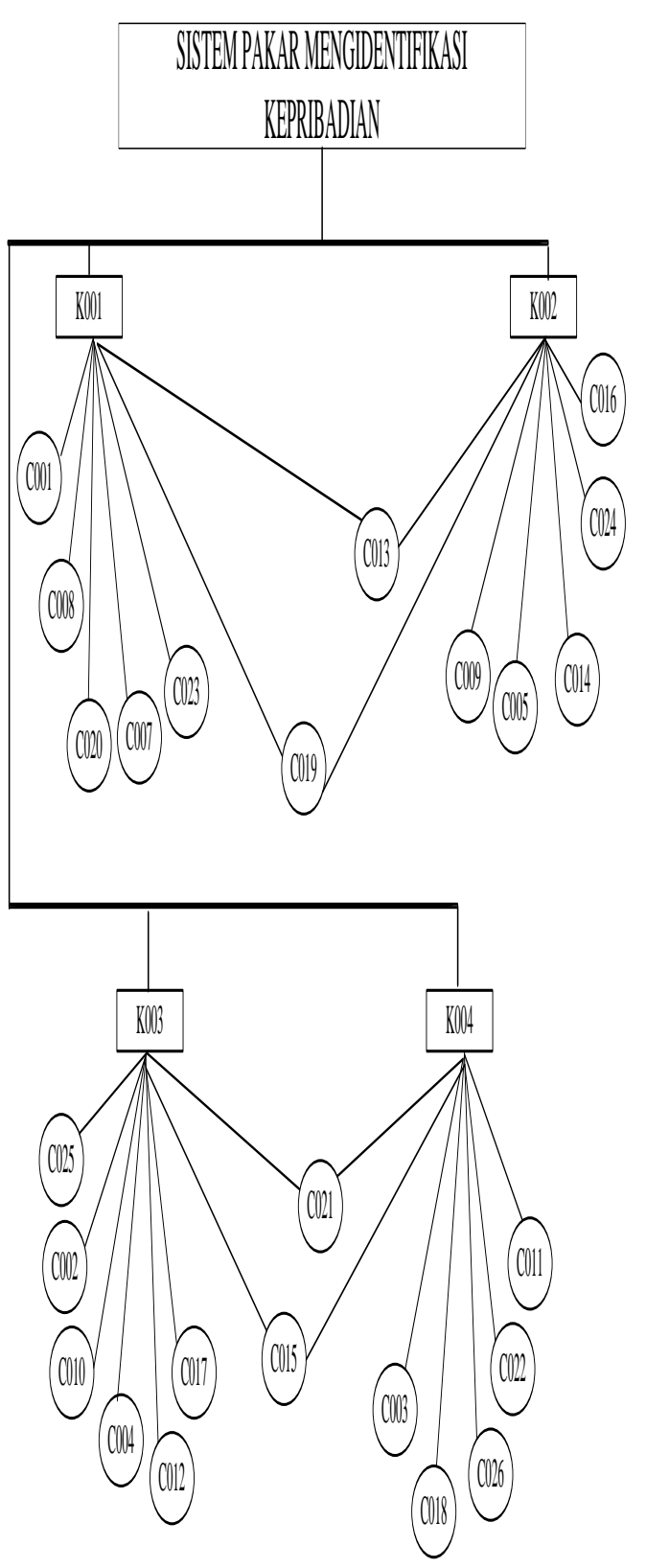

Gambar. 2 Pohon Keputusan

Berdasarkan dari pohon keputusan yang telah dibuatmaka didapat rule-rule dari aplikasi Sistem Pakar untuk mengidentifikasi kepribadian siswa yaitu seperti pada tabel 4berikut : 
Tabel. 4 Aturan Kepribadian dengan Ciricirinya

\begin{tabular}{|c|c|c|c|}
\hline NO & IF & THEN & $\begin{array}{l}\text { NILAI } \\
\text { CF } \\
\end{array}$ \\
\hline 1 & $\begin{array}{l}\text { C001 AND } \\
\text { C008 AND } \\
\text { C020 AND } \\
\text { C007 AND } \\
\text { C023 AND } \\
\text { C019 AND } \\
\text { C013 }\end{array}$ & $\begin{array}{l}\text { K001 } \\
\text { SANGUI } \\
\text { NIS }\end{array}$ & $\mathrm{CF}=1$ \\
\hline 2 & $\begin{array}{l}\text { C001 AND } \\
\text { C008 }\end{array}$ & $\begin{array}{l}\text { K001 } \\
\text { SANGUI } \\
\text { NIS }\end{array}$ & $\begin{array}{l}\mathrm{CF}= \\
0,2\end{array}$ \\
\hline 3 & $\begin{array}{l}\text { C001 AND } \\
\text { C008 AND } \\
\text { C020 }\end{array}$ & $\begin{array}{l}\text { K001 } \\
\text { SANGUI } \\
\text { NIS }\end{array}$ & $\begin{array}{l}\mathrm{CF}= \\
0,4\end{array}$ \\
\hline 4 & $\begin{array}{l}\text { C001 AND } \\
\text { C008 AND } \\
\text { C020 AND } \\
\text { C007 }\end{array}$ & $\begin{array}{l}\text { K001 } \\
\text { SANGUI } \\
\text { NIS }\end{array}$ & $\begin{array}{l}\mathrm{CF}= \\
0,6\end{array}$ \\
\hline 5 & $\begin{array}{l}\text { C001 AND } \\
\text { C008 AND } \\
\text { C020 AND } \\
\text { C007 AND } \\
\text { C023 }\end{array}$ & $\begin{array}{l}\text { K001 } \\
\text { SANGUI } \\
\text { NIS }\end{array}$ & $\begin{array}{l}\mathrm{CF}= \\
0,7\end{array}$ \\
\hline 6 & $\begin{array}{l}\text { C001 AND } \\
\text { C008 AND } \\
\text { C020 AND } \\
\text { C007 AND } \\
\text { C023 AND } \\
\text { C019 }\end{array}$ & $\begin{array}{l}\text { K001 } \\
\text { SANGUI } \\
\text { NIS }\end{array}$ & $\begin{array}{l}\mathrm{CF}= \\
0,8\end{array}$ \\
\hline 7 & $\begin{array}{l}\text { C013 AND } \\
\text { C019 AND } \\
\text { C009 AND } \\
\text { C005 AND } \\
\text { C014 AND } \\
\text { C024 AND } \\
\text { C01 }\end{array}$ & $\begin{array}{l}\text { K002 } \\
\text { KOLERI } \\
\text { S }\end{array}$ & $\mathrm{CF}=1$ \\
\hline 8 & $\begin{array}{l}\text { C013 AND } \\
\text { C019 }\end{array}$ & $\begin{array}{l}\text { K002 } \\
\text { KOLERI } \\
\text { S } \\
\end{array}$ & $\begin{array}{l}\mathrm{CF}= \\
0,2\end{array}$ \\
\hline 9 & $\begin{array}{l}\text { C013 AND } \\
\text { C019 AND } \\
\text { C009 }\end{array}$ & $\begin{array}{l}\text { K002 } \\
\text { KOLERI } \\
\text { S } \\
\end{array}$ & $\begin{array}{l}\mathrm{CF}= \\
0,3\end{array}$ \\
\hline 10 & $\begin{array}{l}\text { C013 AND } \\
\text { C019 AND } \\
\text { C009 AND } \\
\text { C005 }\end{array}$ & $\begin{array}{l}\text { K002 } \\
\text { KOLERI } \\
\text { S }\end{array}$ & $\begin{array}{l}\mathrm{CF}= \\
0,4\end{array}$ \\
\hline 11 & $\begin{array}{l}\text { C013 AND } \\
\text { C019 AND } \\
\text { C009 AND } \\
\text { C005 AND } \\
\text { C014 }\end{array}$ & $\begin{array}{l}\text { K002 } \\
\text { KOLERI } \\
\mathrm{S}\end{array}$ & $\begin{array}{l}\mathrm{CF}= \\
0,6\end{array}$ \\
\hline 12 & C013 AND & K002 & $\mathrm{CF}=$ \\
\hline
\end{tabular}

\begin{tabular}{|c|c|c|c|}
\hline & $\begin{array}{l}\text { C019 AND } \\
\text { C009 AND } \\
\text { C005 AND } \\
\text { C014 AND } \\
\text { C024 }\end{array}$ & $\begin{array}{l}\text { KOLERI } \\
\mathrm{S}\end{array}$ & 0,7 \\
\hline 13 & $\begin{array}{l}\text { C025 AND } \\
\text { C002 AND } \\
\text { C010 AND } \\
\text { C004 AND } \\
\text { C012 AND } \\
\text { C017 AND } \\
\text { C015 }\end{array}$ & $\begin{array}{l}\text { K003 } \\
\text { MELAN } \\
\text { KOLIS }\end{array}$ & $\mathrm{CF}=1$ \\
\hline 14 & $\begin{array}{l}\text { C025 AND } \\
\text { C002 }\end{array}$ & $\begin{array}{l}\text { K003 } \\
\text { MELAN } \\
\text { KOLIS }\end{array}$ & $\begin{array}{l}\mathrm{CF}= \\
0,2\end{array}$ \\
\hline 15 & $\begin{array}{l}\text { C025 AND } \\
\text { C002 AND } \\
\text { C010 }\end{array}$ & $\begin{array}{l}\text { K003 } \\
\text { MELAN } \\
\text { KOLIS } \\
\end{array}$ & $\begin{array}{l}\mathrm{CF}= \\
0,3\end{array}$ \\
\hline 16 & $\begin{array}{l}\text { C025 AND } \\
\text { C002 AND } \\
\text { C010 AND } \\
\text { C004 }\end{array}$ & $\begin{array}{l}\text { K003 } \\
\text { MELAN } \\
\text { KOLIS }\end{array}$ & $\begin{array}{l}\mathrm{CF}= \\
0,4\end{array}$ \\
\hline 17 & $\begin{array}{l}\text { C025 AND } \\
\text { C002 AND } \\
\text { C010 AND } \\
\text { C004 AND } \\
\text { C012 }\end{array}$ & $\begin{array}{l}\text { K003 } \\
\text { MELAN } \\
\text { KOLIS }\end{array}$ & $\begin{array}{l}\mathrm{CF}= \\
0,6\end{array}$ \\
\hline 18 & $\begin{array}{l}\text { C025 AND } \\
\text { C002 AND } \\
\text { C010 AND } \\
\text { C004 AND } \\
\text { C012 AND } \\
\text { C017 }\end{array}$ & $\begin{array}{l}\text { K003 } \\
\text { MELAN } \\
\text { KOLIS }\end{array}$ & $\begin{array}{l}\mathrm{CF}= \\
0,7\end{array}$ \\
\hline 19 & $\begin{array}{l}\text { C021 AND } \\
\text { C003 AND } \\
\text { C018 AND } \\
\text { C026 AND } \\
\text { C022 AND } \\
\text { C011 AND } \\
\text { C015 }\end{array}$ & $\begin{array}{l}\text { K004 } \\
\text { PLEGH } \\
\text { MATIS }\end{array}$ & $\mathrm{CF}=1$ \\
\hline 20 & $\begin{array}{l}\text { C021 AND } \\
\text { C003 }\end{array}$ & $\begin{array}{l}\text { K004 } \\
\text { PLEGH } \\
\text { MATIS }\end{array}$ & $\begin{array}{l}\mathrm{CF}= \\
0,2\end{array}$ \\
\hline 21 & $\begin{array}{l}\text { C021 AND } \\
\text { C003 AND } \\
\text { C018 }\end{array}$ & $\begin{array}{l}\text { K004 } \\
\text { PLEGH } \\
\text { MATIS }\end{array}$ & $\begin{array}{l}\mathrm{CF}= \\
0,3\end{array}$ \\
\hline 22 & $\begin{array}{l}\text { C021 AND } \\
\text { C003 AND } \\
\text { C018 AND } \\
\text { C026 }\end{array}$ & $\begin{array}{l}\text { K004 } \\
\text { PLEGH } \\
\text { MATIS }\end{array}$ & $\begin{array}{l}\mathrm{CF}= \\
0,4\end{array}$ \\
\hline 23 & $\begin{array}{l}\text { C021 AND } \\
\text { C003 AND } \\
\text { C018 AND } \\
\text { C026 AND } \\
\text { C022 }\end{array}$ & $\begin{array}{l}\text { K004 } \\
\text { PLEGH } \\
\text { MATIS }\end{array}$ & $\begin{array}{l}\mathrm{CF}= \\
0,6\end{array}$ \\
\hline 24 & C021 AND & K004 & $\mathrm{CF}=$ \\
\hline
\end{tabular}




\begin{tabular}{lll}
\hline C003 AND & PLEGH & 0,7 \\
C018 AND & MATIS & \\
C026 AND & & \\
C022 AND & & \\
C011 & & \\
\hline
\end{tabular}

Pada sesi konsultasi sistem, user diberi pilihan jawaban di mana saya memberikan lima pilihan jawaban yang masing-maisng bobot sebagai berikut :

Tabel. 5 Tabel Tingkat Keyakinan

\begin{tabular}{lc}
\hline \multicolumn{1}{c}{ Certainty Term } & CF \\
\hline Pasti Tidak & 0,1 \\
Hampir Tidak Pasti & 0,2 \\
Kemungkinan Besar Tidak & 0,3 \\
Mungkin Tidak & 0,4 \\
Tidak Tahu & 0,5 \\
Mungkin & 0.6 \\
Kemungkinan Besar & 0,7 \\
Hampir Pasti & 0,8 \\
Pasti & 1 \\
\hline
\end{tabular}

Nilai 0,1 menunjukkan bahwa user tidak mengalami gejala seperti yang dinyatakan oleh sistem. Semakin user yakin bahwa ciri-ciri tersebut memang dialami, maka semakin tinggi pula hasil persentase keyakinan total yang diperoleh.

Proses penghitungan persentase keyakinan diawali dengan pemecahan sebuah kaidah (rule) yang memiliki premis majemuk, menjadi kaidahkaidah (rules) yang memiliki premis tunggal. Kemudian masing-masing rule baru dihitung $\mathrm{CF}$ nya dengan menggunakan persamaan sehingga setelah diperoleh nilai $\mathrm{CF}$ untuk masing-masing rule, kemudian nilai $\mathrm{CF}$ tersebut dikombinasikan dengan persamaan Dari dialog user dengan sistem, yang mana dialog user tersebut terdapat pada halaman lampiran pada tesis ini maka diperoleh fakta karakteristik.

Fakta karakteristik psikopat tersebut dapat dilihat atau diuraikan pada tabel 6 sebagai berikut :
Tabel. 6 Fakta Karakteristik

\begin{tabular}{|c|c|c|c|}
\hline Fakta & & $\begin{array}{l}\text { Certainty } \\
\text { Term }\end{array}$ & $\begin{array}{l}\text { Nilai } \\
\text { CF }\end{array}$ \\
\hline $\mathrm{C} 001$ & Evidence & Pasti & $\begin{array}{l}\mathrm{CF}= \\
1,0\end{array}$ \\
\hline $\mathrm{C} 002$ & Evidence & Hampir Pasti & $\begin{array}{l}\mathrm{CF}= \\
0,80\end{array}$ \\
\hline $\mathrm{C} 003$ & Evidence & $\begin{array}{l}\text { Kemungkinan } \\
\text { Besar }\end{array}$ & $\begin{array}{l}\mathrm{CF}= \\
0,70\end{array}$ \\
\hline $\mathrm{C} 005$ & Evidence & Mungkin & $\begin{array}{l}\mathrm{CF}= \\
0,60\end{array}$ \\
\hline C006 & Evidence & Pasti & $\begin{array}{l}\mathrm{CF}= \\
1,0\end{array}$ \\
\hline $\mathrm{C} 007$ & Evidence & Hampir Pasti & $\begin{array}{l}\mathrm{CF}= \\
0,80\end{array}$ \\
\hline C008 & Evidence & $\begin{array}{l}\text { Kemungkinan } \\
\text { Besar }\end{array}$ & $\begin{array}{l}\mathrm{CF}= \\
0,70\end{array}$ \\
\hline $\mathrm{C} 010$ & Evidence & $\begin{array}{l}\text { Kemungkinan } \\
\text { Besar }\end{array}$ & $\begin{array}{l}\mathrm{CF}= \\
0,70\end{array}$ \\
\hline C014 & Evidence & Pasti & $\begin{array}{l}\mathrm{CF}= \\
1,0\end{array}$ \\
\hline C016 & Evidence & $\begin{array}{l}\text { Kemungkinan } \\
\text { Besar }\end{array}$ & $\begin{array}{l}\mathrm{CF}= \\
0,70\end{array}$ \\
\hline C019 & Evidence & Mungkin & $\begin{array}{l}\mathrm{CF}= \\
0,60\end{array}$ \\
\hline $\mathrm{C} 020$ & Evidence & Pasti Tidak & $\begin{array}{l}\mathrm{CF}= \\
0,10\end{array}$ \\
\hline $\mathrm{C} 021$ & Evidence & Pasti & $\begin{array}{l}\mathrm{CF}= \\
1,0\end{array}$ \\
\hline $\mathrm{C} 023$ & Evidence & Pasti & $\begin{array}{l}\mathrm{CF}= \\
1,0\end{array}$ \\
\hline $\mathrm{C} 024$ & Evidence & Pasti Tidak & $\begin{array}{l}\mathrm{CF}= \\
0,10\end{array}$ \\
\hline $\mathrm{C} 025$ & Evidence & Hampir Pasti & $\begin{array}{l}\mathrm{CF}= \\
0,80\end{array}$ \\
\hline C026 & Evidence & Mungkin & $\begin{array}{l}\mathrm{CF}= \\
0,60\end{array}$ \\
\hline
\end{tabular}

Setelah fakta karakteristik didapatkan dari user (pengguna), maka proses selanjutnya adalah sistem memeriksa karakteristik yang ada di dalam rule. Adapun rule - rule yang akan diproses berdasarkan dialog user dengan sistem dapat dilihat pada tabel di bawah ini :

Tabel. 7 Nilai CF Rule

\begin{tabular}{llll}
\hline No & Rule & & Nilai CF \\
\hline 1. & IF C001 & AND & CF $=0,8$ \\
& C008 & AND & \\
C020 & AND & \\
C007 & AND & \\
& C023 & AND & \\
\hline
\end{tabular}




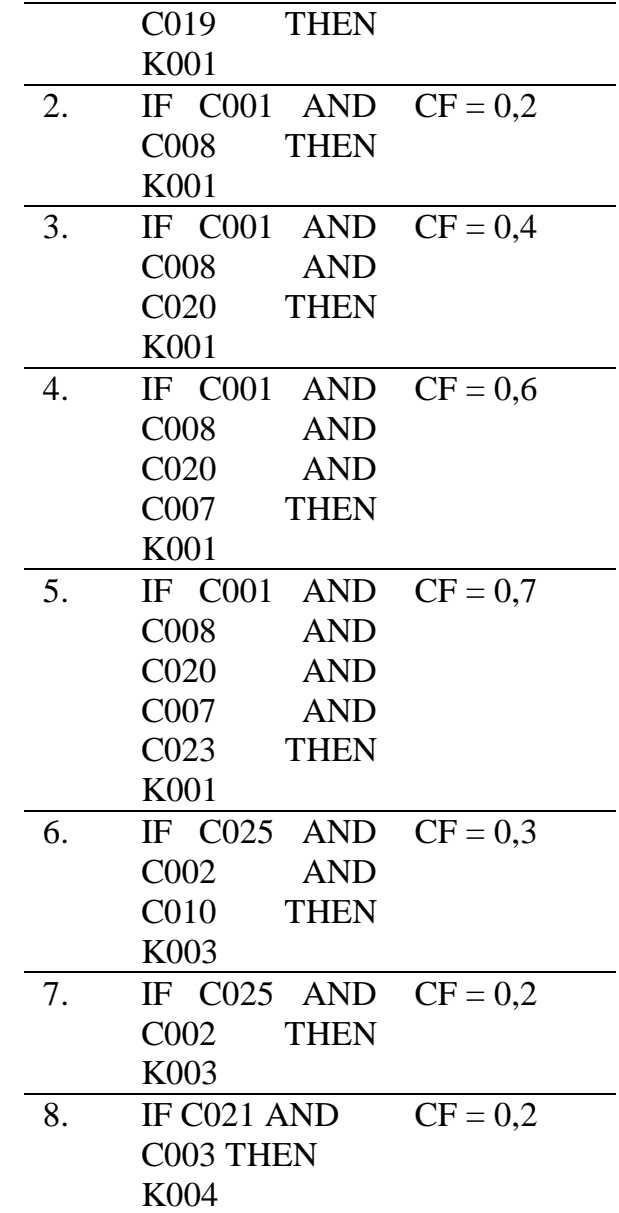

Setelah rule - rule diketahui maka langkah selanjutnya adalah melakukan perhitungan pencarian nilai Hypothesis (fakta baru)dengan menggunakan rumus Certainty Faktor yaitu $C F(A A N D B)$ $=\operatorname{Min}(C F(A), C F(B)) * C F$ (rule ). Adapun perhitungannya dapat dilihat sebagai berikut :

Rule $1=$ Tidak dieksekusi karena Evidence Tidak Fakta.

Rule $2=$ IF C001 (1,0) and C008 $(0,70)$ Then K001 ( CF = 0,2)

CF2 (K001.C001 ค C008)

$=\operatorname{Min}[1,0 ; 0,70] * 0,2$

$=0,14$

Fakta Baru :

K001 Hypothesis $\mathrm{CF}=0,14$
Rule 3 = IF C001 $(1,0)$ and C008 $(0,70)$ and C020 $(1,0)$ Then K001 ( CF $=0,4$ )

C020)

$0,4 \quad=\operatorname{Min} 1$

Fakta Baru :

K001 Hypothesis $\mathrm{CF}=0,28$

Rule $4=$ IF C001 $(1,0)$ and $\mathrm{C} 008(0,70)$ and $\mathrm{C} 020(1,0)$ and $\mathrm{C} 007$ $(0,70)$ Then K001 ( $\mathrm{CF}=0,6)$

CF3 (K001.C001 a C008 ? $\mathrm{C} 029$ ○ C007) $=\operatorname{Min}[1,0 ; 0,70 ; 1,0 ;$

$0,70] * 0,6$

$$
=0,42
$$

Fakta Baru :

K001 Hypothesis $\mathrm{CF}=0,42$

Rule $5=$ IF C001 (1,0) and C008 $(0,70)$ and C020 $(1,0)$ and C007 $(0,70)$ and C023 $(0,1)$ Then K001 ( CF $=0,7$ )

CF3 (K001.C001 ค $\mathrm{C008}$ ○ $\mathrm{C} 020$ ○ 007 ○ 023$)$

$0,70 ; 0,1] * 0,7$

$$
=\operatorname{Min}[1,0 ; 0,70 ; 1,0 ;
$$

Fakta Baru :

$$
=0,07
$$

K001 Hypothesis $\mathrm{CF}=0,07$

Rule $6=\mathrm{IF} \mathrm{C001}(1,0)$ and C008 $(0,70)$ and C020 $(1,0)$ and C007 $(0,70)$ and $\mathrm{C} 023(0,1)$ and $\mathrm{C} 019(0,80)$ Then K001 ( $\mathrm{CF}=0,8$ )

CF3 (K001.C001 ค $\mathrm{C008}$ ○ $\mathrm{C} 020$ ○ $\mathrm{C007}$ ○ $\mathrm{C} 023$ ○ $\mathrm{C} 019)$

$0,70 ; 0,1 ; 0,80] * 0,8$

$$
=\operatorname{Min}[1,0 ; 0,70 ; 1,0 ;
$$

$$
=0,08
$$

Fakta Baru :

K001 Hypothesis $\mathrm{CF}=0,08$

Rule $7=$ tidak dieksekusi karena evidence tidak fakta. 
Rule $8=$ tidak dieksekusi karena evidence tidak fakta.

Rule $9=$ Tidak dieksekusi karena evidence tidak fakta.

Rule $10=$ Tidak dieksekusi karena evidence tidak fakta.

Rule $11=$ Tidak dieksekusi karena evidence tidak fakta.

Rule $12=$ Tidak dieksekusi karena evidence tidak fakta.

Rule $13=$ Tidak dieksekusi karena evidence tidak fakta.

Rule $14=\operatorname{IF~C025~}(0,80)$ and C002 $(0,80)$ Then K003 ( $\mathrm{CF}=0,2)$

CF21 (K004.C025 ^ C002)

$=\operatorname{Min}[0,80 ; 0,80] * 0,2$

Fakta Baru :

$$
=0,16
$$

K003Hypothesis $\mathrm{CF}=0,16$

Rule $15=\operatorname{IF~C025~}(0,80)$ and $\mathrm{C} 002(0,80)$ and $\mathrm{C} 010(0,70)$ Then $\mathrm{K} 003(\mathrm{CF}=0,3)$ C010) CF21 (K004.C025 ค C002 。

$=\operatorname{Min}[0,80 ; 0,80 ; 0.70] * 0,3$ $=0,21$

Fakta Baru :

K003Hypothesis $\mathrm{CF}=0,21$

Rule $16=$ Tidak dieksekusi karena evidence tidak fakta.

Rule 17 = Tidak dieksekusi karena evidence tidak fakta.

Rule $18=$ Tidak dieksekusi karena evidence tidak fakta.

Rule $19=$ Tidak dieksekusi karena evidence tidak fakta.
Rule $20=$ IF C021 (1) and C003 $(0,70)$ Then K004 ( $\mathrm{CF}=0,2)$

CF21 (K004.C021 ค C003)

$$
=\operatorname{Min}[1 ; 0,70] * 0,2
$$$$
=0,14
$$

Fakta Baru :

P004 Hypothesis $\mathrm{CF}=0,14$

Rule $21=$ Tidak dieksekusi karena evidence tidak fakta.

Rule $22=$ Tidak dieksekusi karena evidence tidak fakta.

Rule 23 = Tidak dieksekusi karena evidence tidak fakta.

Rule 24 = Tidak dieksekusi karena evidence tidak fakta.

Setelah perhitungan selesai dari setiap rule - rule yang terpilih. Maka diperoleh hasil hypothesis atau fakta baru yang terdapat pada tabel 8 sebagai berikut :

Tabel. 8 Fakta Baru

\begin{tabular}{ccc}
\hline $\begin{array}{c}\text { Fakta } \\
\text { Baru }\end{array}$ & Nilai CF \\
\hline K001 & Hypothesis & 0,14 \\
K001 & Hypothesis & 0,28 \\
K001 & Hypothesis & 0,42 \\
K001 & Hypothesis & 0,07 \\
K001 & Hypothesis & 0,08 \\
K003 & Hypothesis & 0,16 \\
K003 & Hypothesis & 0,21 \\
K004 & Hypothesis & 0,14 \\
\hline
\end{tabular}

Dari tabel fakta baru di atas dapat kita lihat, terdapat hasil hypothesis yang sama. Maka langkah selanjutnya adalah melakukan perhitungan $\mathrm{CF}$ gabungan (kombinasi) dengan menggunakan rumus $C F 1+$ $C F 2 *(1-C F 1)$ atau dengan kata lain dilakukan penjumlahan terhadap setiap nilai fakta baru per setiap jenis kemudian total penjumlahan dikalikan dengan satu dikurang nilai maksimum 
dari hasil fakta baru per setiap jenis. Setelah hasilnya didapatkan maka dikalikan dengan $100 \%$.

Fakta Baru :

1. $(\mathrm{CF} 2+\mathrm{CF} 3+\mathrm{CF} 4+\mathrm{CF} 5+\mathrm{CF} 6) *(1-$ $\mathrm{CF} 3$ )

$$
\begin{aligned}
& =(0,14+0,28+0,42+0,07+ \\
0,08) & *(1-0,42) \\
& =0,99 * 0,58 \\
& =0,5742
\end{aligned}
$$

Hasil Kombinasi dikali $100 \%=$ $0,5742 * 100 \%=57,42 \%$

2. $(\mathrm{CF} 14+\mathrm{CF} 15) *(1-\mathrm{CF} 15)$

$$
\begin{aligned}
& =(0,16+0,21) *(1-0,21) \\
& =0,37 * 0,79 \\
& =0,2923
\end{aligned}
$$

Hasil Kombinasi dikali $100 \%=$ $0,2923 * 100 \%=29,23 \%$

3. $(\mathrm{CF} 20) *(1-\mathrm{CF} 20)$

$$
\begin{aligned}
& =(0,14) *(1-0,14) \\
& =0,14 * 0,86 \\
& =0,1204
\end{aligned}
$$

\begin{tabular}{|c|c|c|c|c|}
\hline $\begin{array}{c}\text { Kode } \\
\text { Keprib } \\
\text { adian }\end{array}$ & $\begin{array}{c}\text { Jenis } \\
\text { Kepribadi } \\
\text { an } \\
\end{array}$ & Rule & $\begin{array}{l}\text { Nil } \\
\text { ai } \\
\text { CF }\end{array}$ & $\begin{array}{l}\text { Hasil } \\
\text { Kombi } \\
\text { nasi }\end{array}$ \\
\hline K001 & Sanguinis & $\begin{array}{c}\text { Rule } \\
2\end{array}$ & 0,14 & \\
\hline K001 & Sanguinis & $\begin{array}{c}\text { Rule } \\
3\end{array}$ & 0,28 & \\
\hline K001 & Sanguinis & $\begin{array}{c}\text { Rule } \\
4\end{array}$ & 0,42 & $\begin{array}{l}57,42 \\
\%\end{array}$ \\
\hline K001 & Sanguinis & $\begin{array}{c}\text { Rule } \\
5\end{array}$ & 0,07 & \\
\hline K001 & Sanguinis & $\begin{array}{c}\text { Rule } \\
6\end{array}$ & 0,08 & \\
\hline K003 & Melankolis & $\begin{array}{c}\text { Rule } 1 \\
4\end{array}$ & 0,16 & 29,23 \\
\hline
\end{tabular}

Hasil Kombinasi dikali $100 \%=$ $0,1204 * 100 \%=12,04 \%$

Setelah hasil kombinasi didapatkan agar memudahkan untuk melihat hasil yang akan diperoleh oleh user. Maka dapat dibuat tabel hasil sebagai berikut :

Tabel. 9 Hasil Kombinasi dan Nilai CF

\begin{tabular}{ccccc}
\hline K003 & Melankolis & Rule 1 & 0,21 & \\
& 5 & & \\
K004 & Pleghmatis & Rule2 & 0,14 & 12,04 \\
& & 0 & & $\%$ \\
\hline
\end{tabular}

Dari tabel hasil kombinasi dan nilai $\mathrm{CF}$ di atas maka dapat dibuat tabel baru, di mana tabel tersebut menjelaskan urutan hasil kombinasi dan nilai $\mathrm{CF}$ yang terbesar kenilai yang terkecil.

Tabel. 10 Urutan Nilai Hasil Kombinasi Dan Nilai CF

\begin{tabular}{ccc}
\hline $\begin{array}{c}\text { Kode } \\
\text { Psikopat }\end{array}$ & $\begin{array}{c}\text { Jenis } \\
\text { Psikopat }\end{array}$ & $\begin{array}{c}\text { Hasil } \\
\text { Kombinasi }\end{array}$ \\
\hline P001 & Pedofilia & $57,42 \%$ \\
P004 & Anti Sosial & $29,23 \%$ \\
P005 & Sosiopat & $12,04 \%$ \\
\hline
\end{tabular}

Kesimpulan dari tabel urutan nilai hasil kombinasi dan nilai $\mathrm{CF}$ di atas dapat dilihat jenis kepribadian yang dimiliki oleh user adalah Melankolis dengan Tingkat Kepastian 0,5742 atau dengan $57,42 \%$.

Certainty theory mendasari penggunaan Certainty Factors (CFs). CFs mengekspresikan kepercayaan dalam kejadian (atau fakta atau hipotesis) berdasarkan kejadian atau penilaian seorang pakar. Sari (2013) meneliti penggunaan metode Certainty Factor (CF) dalam sistem pakar dalam mendiagnosa penyakit demam berdarah.

Certainty Factor (CF) digunakan untuk menyatakan tingkat keyakinan pakar dalam suatu pernyataan (Levine, 1988). Certainty Factor dinilai dengan angka dalam rentang -1 (yakin negatif) sampai 1 (yakin positif).

Faktor kepastian merupakan suatu metode untuk membuktikan apakah suatu fakta itu pasti ataukah tidak pasti yang berbentuk metric yang biasanya digunakan dalam sistem pakar. Metode ini sangat cocok untuk sistem pakar 
yang mendiagnosis sesuatu yang belum pasti (Kusumadewi, 2003). Dalam mengekpresikan derajat keyakinan digunakan suatu nilai yang disebut Certainty Factor (CF) untuk mengasumsikan derajat keyakinan seorang pakar terhadap suatu data.

Aplikasi yang dibangun menggunakan metode certainty factor, yang mencoba melihat apakah sebuah fakta bersifat pasti atau tidak pasti. Metode tersebut digunakan karena dapat memberikan hasil yang akurat yang didapatkan dari perhitungan berdasarkan bobot gejala yang dipilih oleh pakar, mampu memberikan jawaban pada permasalahan yang tidak pasti. Metode ini memperhitungkan faktor tingkat keyakinan seorang pakar dengan memberikan bobot keyakinan sesuai dengan pengetahuan pakar (Indriani, 2018).

Metode certainty factor ini telah dicermati oleh peneliti lain untuk berbagai pengamatan dan penerapan. Penerapan metode ini berhasil dalam proses penentuan jurusan di SMA berdasarkan nilai akademik dan tes psikologi. Di bidang kedokteran, penerapan metode certainty factor berhasil mendeteksi penyakit akibat kekurangan gizi pada usia produktif, dan penentuan penyait kulit dan kelamin, mendiagnosis penyakit infeksi saluran pernapasan atas, diagnosis penyakit pada ayam broilen (Cikraeni, 2015; Wulandari, 2014; Krisnawan, 2014; Septian, 2016 \& Rahmah, 2017).

\section{SIMPULAN}

Dari hasil penelitian sampai tahap implementasi dan pengujian sistem, maka dapat diperoleh kesimpulan sebagai berikut :

1. Sistem Pakar untuk mengidentifikasi kepribadian ini ditujukan untuk mencari dan mendapatkan solusi atas permasalahan guru terhadap pendekatan kepada siswa guna mengantarkan materi pembelajaran agar sampai kepada siswa.

2. Sistem Pakar ini dapat memberi kemudahan kepadauser karena dengan menggunakan website dimana bisa diakses dari mana saja.

3. Metode Certainty Factor dapat digunakan untuk proses mengidentifikasi kepribadian sesuai dengan bobot dari nilai tingkat keyakinan dan solusi perbaikannya. 
DAFTAR PUSTAKA

Bassil, Y. (2012). Experet PC Troubleshooter with Fuzzy-Logic And Self-Learning Support. International Journal of Artificial Intelligence \& Applications (IJAIA), 3(2), 11-21

Cikraeni, T. A., \& Ruliah, R. (2015). Penerapan Metode Certainty Factor untuk Keputusan Pemilihan Jurusan di SMA," Progressif, 9(1)

Giarattano, J. \& Riley, G. (1994), Expert System Principles and Programming. Boston: PWS Publishing Company

Halim, S., \& Hansun, S. (2015). Penerapan Metode Certainty Factor dalam Sistem Pakar Pendeteksi Resiko Osteoporosis dan Osteoarthritis," ISSN 23553286, 7(2), 59-69

Indriani, A. F., Rachmawati, E. Y., \& Fitriana, J. D. (2018). Pemanfaatan Metode Certainty Factor dalam Sistem Pakar Diagnosa Penyakit pada Anak," Techno.Com, 17(1), 12-22

Intan, R \& Gregorius, S. B. (2010). Proposal Penerapan Probabilitas Penggunaan Fakta Guna Menentukan Certainly Factor pada Rule Base Expert System. Surabaya: UK Petra

Josephine, M. S., \& Jeyabalaraja, V. (2012). Expert System and Knowledge Management for Software Developer in Software Companies. Software Engineering and Technology, 4(4), 147-151

Kemendikbud. (2016). Pengembangan Bakat dan Minat. Jakarta

Krisnawan, I. P. B., Putra, I. K. G. D., \& Bayupati, I. P. A. (2014). Sistem Pakar Diagnosa Penyakit Kulit dan Kelamin. J. Ilm. Merpati (Menara Penelit. Akad. Teknol. Informasi)
Kusumadewi, S. (2003). Artificial Intelegence (Teknik dan Aplikasinya). Yogyakarta: Graha Ilmu

Levine, R. I. (1998). A Comprehensive guide to AI and Expert Systems Using Turbo Pascal International Edition. Singapore: McGraw-Hill Book Co

Nurihsan, J., \& Agustin, M. (2013). Dinamika Perkembangan Anak dan Remaja. Bandung: PT. Refika Aditama

Rahmah, J., \& Saputra, R. A. (2017). Penerapan Certainty Factor pada Sistem Pakar Diagnosa Penyakit Saluran Pencernaan Ayam Broiler," J. Inform, 4(1), 94-102

Romeo, M., Mateo, A., \& Lee, J. (2008). Healthcare Expert System based on Group Cooperation Model. International Journal of Software Engineering and Its Application, 2(1)

Salisah, F. N., Lidya, L., \& Defit, S. (2015). Sistem Pakar Penentuan Bakat Anak dengan Menggunakan Metode Forward Chaining. J. Ilm. Rekayasa dan Manaj. Sist. Inf, 1(1), 62-66

Sari, N. A. (2013). Sistem Pakar Mendiagnosa Penyakit Demam Berdarah Menggunakan Metode Certainty Factor. Pelita Inform. Budi Darma, 4, 100-103

Septiana, L. (2016). Perancangan Sistem Pakar Diagnosa Penyakit Ispa dengan Metode Certainty Factor Berbasis Android. $J$. Techno Nusa Mandiri, 13(2), 1-7

Wulandari, F., \& Yuliandri, I. (2014). Diagnosa Gangguan Gizi Menggunakan Metode Certainty Factor. J. Sains dan Teknol. Ind, 11(2), 305-313 
2018. Intecoms: Journal of Information Technology and Computer Science 1 (1): 78-90

Yulianti, W. (2016). Aptitude Testing Berbasis Case- Based Reasoning dalam Sistem Pakar untuk Menentukan Minat dan Bakat Siswa Sekolah Dasar. J. Teknol. dan Sist. Inf. Univrab, 1(2), 104118 